\title{
Properties of Microcrystalline Chitosan-Calcium Phosphate Complex Composite
}

\author{
Luciano Pighinelli ${ }^{1,2 *}$, Magdalena Kucharska ${ }^{1,2}$ \\ ${ }^{1}$ Lutheran University of Brazil (ULBRA), Canoas, Brazil; ${ }^{2}$ Institute of Biopolymers and Chemical Fibers-IBWCh, Lodz, Poland. \\ Email: "ppgemps@ulbra.br, lpighinelli@hotmail.com, biomater@ibwch.lodz.pl \\ Received October $19^{\text {th }}, 2013$; revised November $22^{\text {nd }}, 2013$; accepted December $4^{\text {th }}, 2013$ \\ Copyright (C) 2013 Luciano Pighinelli, Magdalena Kucharska. This is an open access article distributed under the Creative Commons \\ Attribution License, which permits unrestricted use, distribution, and reproduction in any medium, provided the original work is \\ properly cited. In accordance of the Creative Commons Attribution License all Copyrights (C) 2013 are reserved for SCIRP and the \\ owner of the intellectual property Luciano Pighinelli, Magdalena Kucharska. All Copyright (C) 2013 are guarded by law and by \\ SCIRP as a guardian.
}

\begin{abstract}
Nature itself uses materials like, cellulose to provide the structure of plants, chitin as the exoskeleton of several insects and molluscs, collagen for mechanical support in connective tissues and so on. At present, the socioeconomic situation of the modern world has raised the interest in renewable materials being used in regenerative medicine. The composition of $\mathrm{MCCh} / \beta$-TCP complex in sponge shape is derived from the junction of two or more different materials, containing organic and inorganic materials, including bioactivity and biodegradability as a characteristic. The chemical characteristics of $\mathrm{MCCh} / \mathrm{\beta}$-TCP complex composites showed that both of the components organic and inorganic exist in the material. All sponge preparations, with MCCh/ß-TCP have a well-shaped 3-dimentional structure, a highly porous and interconnected and homogenous pore structure to ensure a biological environment conducive to cell attachment and proliferation as well as tissue growth, providing the passage of nutrient flow. These materials can be used in future for medical applications as a base for scaffolds production and as implants in regenerative medicine.
\end{abstract}

Keywords: Microcrystalline Chitosan; Calcium Phosphate; Functional Biopolymer; Medical Applications

\section{Introduction}

Different types of materials have been developed from chitosan and calcium phosphates that are biocompatible, osteoconductive, resorbable and osteoinductive. The large wide range of materials available for hard tissue regeneration reflects methods of production and application to reconstruct part of skeleton.

All methods may achieve restoration and/or replacement. They all possess inherent limitations, such as use site, donor-site morbidity, an obligatory graft resorption phase, contour irregularities, insufficient autogenous resources, disease transmission, major histocompatibility, structural failure, stress shielding, infection and so on $[1,2]$.

Calcium phosphates, polysaccharides and composite materials, are developed during last 20 years to be used for bone problems. Natural polymers have low mechanical strength compared to bone, and on the other hand

${ }^{*}$ Corresponding author. have good biocompatibility and bioactivity. Ceramics are brittle and have low fracture toughness. With all these properties of polymers, ceramics are together producing composite materials having a reasonable approach [2].

Bone is of composite nature and consists of $69 \mathrm{wt} \%$ calcium phosphate, $21 \%$ collagen (polymer), 9\% water and $1 \%$ other constituents building up a very complex microstructure which is very difficult to imitate and gives most of the superior mechanical properties to bone [2-4].

Biomaterials studies in this research are classified into surface-active materials such as hydroxyapatite (HAp), ß-tricalcium phosphate (ß-TCP), and chitosan and its derivatives such as $\mathrm{MCCh}$ [5-7].

Surface-active materials bind to bone through an apatite layer formed on the material surface after implantation. It is assumed that the velocity of layer formation and new cell correlates with bioactivity. However, how bioactivity affects the formation of the apatite layer is still understudying. It has not been made clear whether the apatite layer can be formed only under the influence 
of the bone tissue [8-10].

Chitosan exhibits a variety of physicochemical and biological properties, such as low toxicity and allergenicity. Its biocompatibility, biodegradability and bioactivity make it a very attractive substance for diverse applications as a biomaterial in pharmaceutical and medical fields [11-14].

Polyaminosaccharides, such as chitosan (poly(B-(1,4)-2amino-2-amino-2-deoxy-D-glucopiranose)) and its derivatives, are characterized by excellent biostimulation properties which facilitate reconstruction and vascularization of damage tissues, and also compensate the shortcomings of cells components $[13,15]$. This cationic property is the basis of many of the potential applications of chitosan and its derivatives that can be considered as a linear polyelectrolyte with a high charge density which can interact with negative charged surfaces, like proteins and anionic polysaccharides $[13,15]$.

Microcrystalline chitosan is characterized by special properties of initial chitosan such as biocompatibility, bioactivity, non-toxic, hydrophility with same creation of molecular and super-molecular structure during its manufacture, in addition, a inner surface formation and reducing the size of crystals in the polymer. It's suitable for medical application, especially for wound dressings and drug delivery [15-17].

The calcium phosphate family constitutes mainly of inorganic materials currently used in dental and orthopedic reconstructive medicine. Specifically, hydroxyapatite (HAp) and B-tricalcium phosphate (B-TCP) were developed as bioceramics in the early 1980s and nowadays are the most common calcium phosphates used in medical applications $[8,18]$. Despite their relative importance, both ceramics show a number of drawbacks that reduce their clinical performance. The biodegradation of HAp in physiological environments is too low to achieve the optimal formation of bone tissue $[8,15,17,18]$.

On the other hand, B-TCP shows fast release of $\mathrm{Ca}^{2+}$ and $\mathrm{PO}_{4}^{3-}$ ions when exposed to physiological fluids and could be considered as bioactive [10]. Selecting the appropriate blend of both calcium phosphates, the mixture gradually dissolves in the physiological environment, releasing $\mathrm{Ca}^{2+}$ and $\mathrm{PO}_{4}^{3-}$ ions and inducing the bioactive behavior suggesting mainly mechanical bonding. The material that remains during dissolution acts as a template for the newly formed bone $[9-11,17,19]$. Biphasic alcium phosphates composites with $\beta$-tricalcium phosphate (ß-TCP), $\mathrm{Ca}_{3}\left(\mathrm{PO}_{4}\right)_{2}$, and hydroxyapatite (HAp), $\mathrm{Ca}_{10}\left(\mathrm{PO}_{4}\right)_{6}(\mathrm{OH})_{2}$, are compounds with a high potential for bio applications, which combine the excellent bioactivity of HAp with the good bioresorbability of B-TCP $[10-12,17,19]$. To improve the suitability of chitosan and its derivatives for bone tissue engineering, the biocom- posites of MCCh, B-TCP and hydroxyapatite could be applied.

\section{Materials and Methods}

\subsection{Materials}

Initial chitosan from Primex Co trade name Chito Clear FG90 was used, characterized by: average molecular weight $\left(\mathrm{M}_{\mathrm{v}}\right)=342 \mathrm{kD}$, deacetylation degree (DD) $=82 \%$, ash content $=1.7 \%$. Microcrystalline chitosan $(\mathrm{MCCh}$ paste) characterized by: average molecular weight $\left(\mathrm{M}_{\mathrm{w}}\right)$ $=330 \mathrm{kD}$, deacetylation degree $(\mathrm{DD})=82 \%$, ash content $=0.7 \%$, water retention value $(\mathrm{WRV})=598 \%$, dry polymer content $=2.79 \%, \mathrm{pH}=7.38$. Microcrystalline chitosan/ß-TCP paste characterized by: water retention value $(\mathrm{WRV})=560 \%$, dry complex content $=3.6 \%$, (Content of MCCh: $80 \%$ and B-TCP: $20 \%$ ), $\mathrm{pH}=7.40$. Tri-calcium phosphate (ß-TCP), $\left(\mathrm{Ca}_{3}\left(\mathrm{Po}_{4}\right)_{2}\right)$-Sigma Aldrich Lab., Germany. Hydroxyapatite $\left(\mathrm{Ca}_{10}\left(\mathrm{Po}_{4}\right)_{6}(\mathrm{OH})_{2}\right)$ - Sigma Aldrich Lab., Germany. Plasticizer-Glycerol $\left(\mathrm{C}_{3} \mathrm{H}_{8} \mathrm{O}_{3}\right) 99 \%$, pure p.a., Sigma-Aldrich, Germany. Hydrochloric ac. $37.8 \%$ p.a., manufactured by Fluka.

\subsection{Methods}

\subsubsection{Analytical Methods for MCCh/ß-TCP Characterization}

1) The water retention value of complex or $\mathrm{MCCh}$ (WRV) is determined by submerging $0.5 \mathrm{~g} \pm 0.0001 \mathrm{~g}$ of MCCh or complex in $50 \mathrm{~cm}^{3}$ of distilled water. Next it is centrifuged for $10 \mathrm{~min}$ at $4000 \mathrm{rpm}$. The weight of the sample is determined after centrifuging and after drying to constant weight after 20 hours at $105^{\circ} \mathrm{C} \pm 1^{\circ} \mathrm{C}$.

2) Determination of complex or MCCh polymer content - approx. $5 \mathrm{~g} \pm 0.0001 \mathrm{~g}$ of complex sample is placed in a laboratory dryer and dried at the temperature of $105^{\circ} \mathrm{C} \pm 1^{\circ} \mathrm{C}$ to constant weight.

3) Deacetylation degree of chitosan or MCCh is determined by the potentiometric titration method using the first derivative UV-spectrophotometry (DUVS). The concentration of chitosan solution is up to $100 \mathrm{~cm}^{3}$ with anhydrous acetic acid $0.0100 \mathrm{M}$. The presence of D-glucosamine was corrected for by a reference curve for $\mathrm{N}$-acetyl-D-glucosamine.

4) Ash content in chitosan or $\mathrm{MCCh}$ - the quartz crucible is heated at $800^{\circ} \mathrm{C}$ for $3 \mathrm{~h}$ to constant weight. After cooling to ambient temperature in the desiccators and weighed on the analytical balance.

\subsubsection{Preparation of Microcrystalline Chitosan/ B-TCP Complex}

Microcrystalline chitosan/ $/$-TCP complex was prepared according to a method elaborated in the Institute of Biopolymers and Chemical Fibers, Polish patent application P 393758 (27/01/2011). 


\subsubsection{Elaboration of the Quantitative and Qualitative Composite MCCh/ß-TCP Complex and HAp}

The main objective of this study was to elaborate qualitative and quantitative composition of $\mathrm{MCCh} / \mathrm{B}$-TCP complex and HAp. The study used a microcrystalline complex form. The quantitative and qualitative compositions of composite are given in Table $\mathbf{1}$.

\subsubsection{Preparation of Composite Sponge}

The preparations were carefully homogenized and next freeze-dried method was applied by dryer ALFA 1 - 4 made by Christ Co. The temperature range from $(-25)$ to $10^{\circ} \mathrm{C}$ and vacuum from 0.1 to 0.53 mbar during 20 to 24 hours depending upon size of the charge. Drying accomplished that way resulted in the preparation of sponges with a smooth surface without defects.

\subsubsection{Preparation of Microcrystalline Chitosan Powder}

The microcrystalline chitosan powder was prepared by freeze-drying method using ALFA 1 - 4 made by Christ Co. The freeze drying proceeded in the temperature range of $(-20)$ to $10^{\circ} \mathrm{C}$ and vacuum $0.1-0.7$ mbar. The drying time was $20-24$ hours to obtain sponge and after the powder.

\subsubsection{SEM Study}

The particle size of commercial ß-TCP and HAp powder and distribution in the polymer matrix in a sponge form, was observed using a scanning electron microscopy (SEM)_FEI Quanta 200, USA.

\subsubsection{Infrared Spectroscopy}

Infrared spectroscopy Fourier transform (FTIR) is a non-destructive technique that was used to identify the functional groups through their chemical bonds, which generate a spectrum of infrared bands characteristic of each connection type. The infrared analysis was in the

Table 1. The formulations characteristic of composites in sponge form.

\begin{tabular}{ccccc}
\hline \multirow{2}{*}{$\begin{array}{c}\text { Symbol of } \\
\text { sample }\end{array}$} & $\begin{array}{c}\text { Weight proportion of components (wt\%) } \\
\text { complex suspension }\end{array}$ & $\begin{array}{c}\text { MCCh } \\
\text { (powder) }\end{array}$ & HAp & Glycerol \\
\cline { 2 - 5 } Sample 1 & $1^{*}$ & 0 & 0 & 0.5 \\
Sample 2 & $1^{*}$ & 0 & 0.5 & 0.5 \\
Sample 3 & $1^{*}$ & 0 & 1 & 0.5 \\
Sample 4 & $1^{*}$ & 0 & 2 & 0.5 \\
Sample 5 & $1^{* *}$ & 0 & 2 & 0.5 \\
Sample 6 & $1^{*}$ & 1 & 2 & 0.5 \\
\hline
\end{tabular}

* Dry complex content $2.0 \% ;{ }^{* *}$ Dry complex content $2.95 \%$. range of 500 to $4000 \mathrm{~cm}^{-1}$, resolution $4.0 \mathrm{~cm}^{-1}$ with a Spectrum Genesis Series. Samples were prepared for analysis with $\mathrm{KBr}$, in the form of tablets. To verify the presence of functional characteristic groups of B-TCP, HAp and MCCh in the composite material.

\subsubsection{Determination of Particles Size in HAp and ß-TCP Powders}

The technique used was by laser particles sizer by Sympatec Hellos H1330, type BF (sympatec GmbH, Clausthal, Germany).

\subsubsection{X-Ray Diffraction}

Two calcium-phosphates in form of powder have been investigated by means of WAXS-diffraction. Both powders HAp and B-TCP were simply placed between two polypropylene films for running the WAXS-scan in transmission mode. The following parameters were adjusted. X-ray radiation- $\mathrm{CuK} \alpha$-doublet, non-monochromatic B-portion suppressed by Ni-filter. Mode of operation-Transmission, anode Voltage - $40 \mathrm{kV}$, tube current $-40 \mathrm{~mA}$, step width $-0.025^{\circ}$, scan rate $-5 \mathrm{sec} / \mathrm{step}$, aperture slit $-1 \mathrm{~mm}$, anti-diffusion slit $-1 \mathrm{~mm}$, detector slit-1 $\mathrm{mm}$.

\subsubsection{Determination of $C a$ and $P$ in HAp and $ß-T C P$ Powders and Composites}

The aim of this study is to determine and compare the quantity of $\mathrm{Ca}$ and $\mathrm{P}$ that remains after sponges preparation of the composites, by ICP-OES, Germany, by method of microwave digestion according to SOP2.5L126, edition 3-quantification of Calcium and Phosphorus (DIN EN ISO 11885).

\section{Results and Discussion}

\subsection{FTIR Study}

The main peaks of energy vibration identified in the composite the $\beta$-TCP, HAp and MCCh (Figures 1 and 2). The characteristic functional groups of orthophosphate $\left(\mathrm{PO}_{4}^{-3}\right)$, hydroxyl $(\mathrm{OH})^{-}$, phosphate $\left(\mathrm{HPO}_{4}^{-2}\right)$ the latter one in trace amount, shown characteristic peaks of calcium phosphates material. The presence of carbonate was observed, in trace, in the commercial B-TCP and HAp material, that suggest in some commercial $B$-TCP and HAp the $\mathrm{CaO}$ and $\mathrm{Ca}(\mathrm{OH})_{2}$ are used to get an ideal stoichiometric relation between $\mathrm{Ca} / \mathrm{P}$ in the material and also related with the preparation process of the samples that were prepare in atmosphere conditions with presence of carbon dioxide and air.

It is known that synthetic B-TCP is the material more stable and more soluble in human body, than HAp, among the calcium phosphates $[9,18,20]$. These features can increase the regeneration of bone tissue in the presence of an implant. 

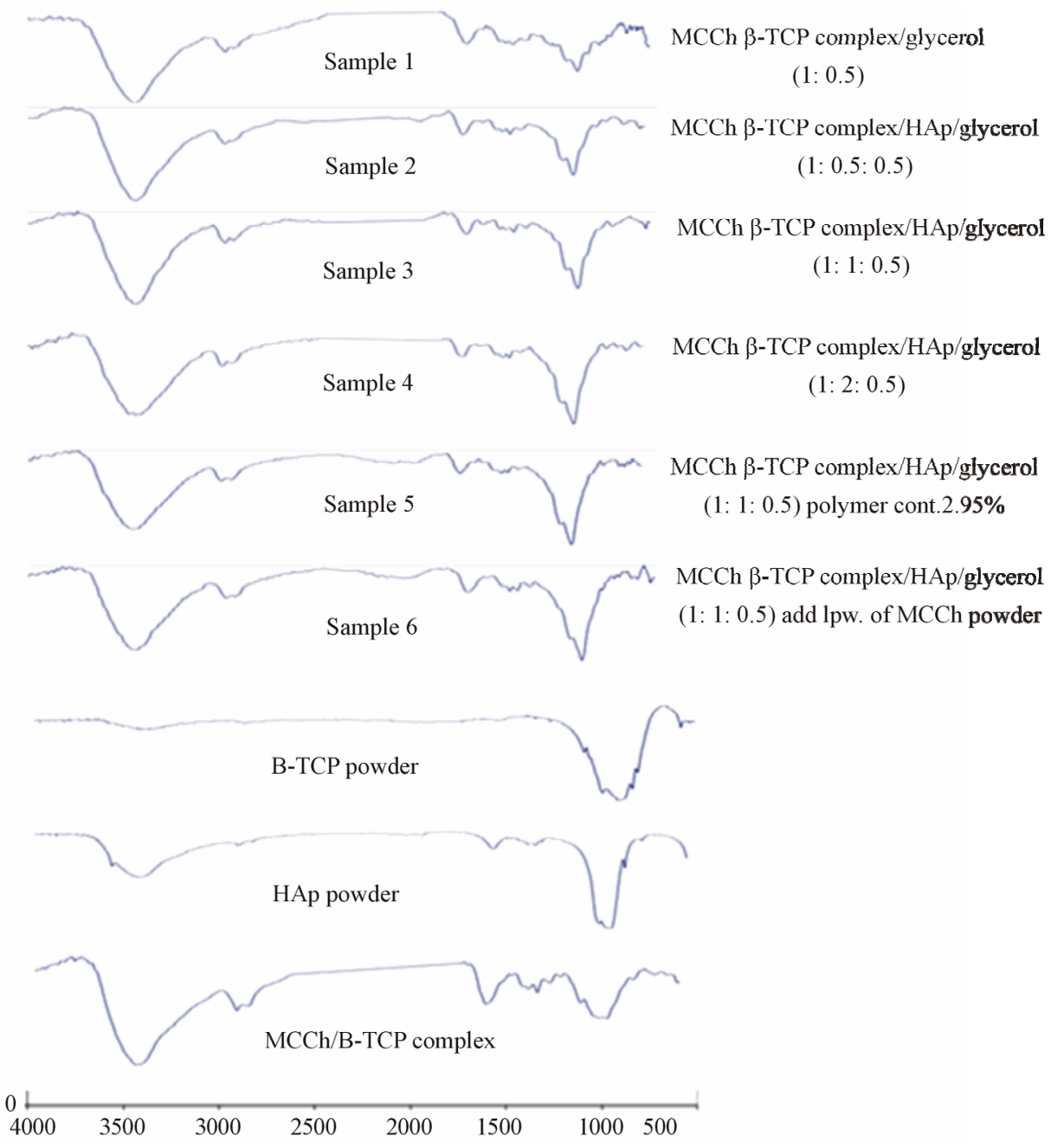

Figure 1. FTIR spectrum of the MCCh/ß-TCP and HAp composites.

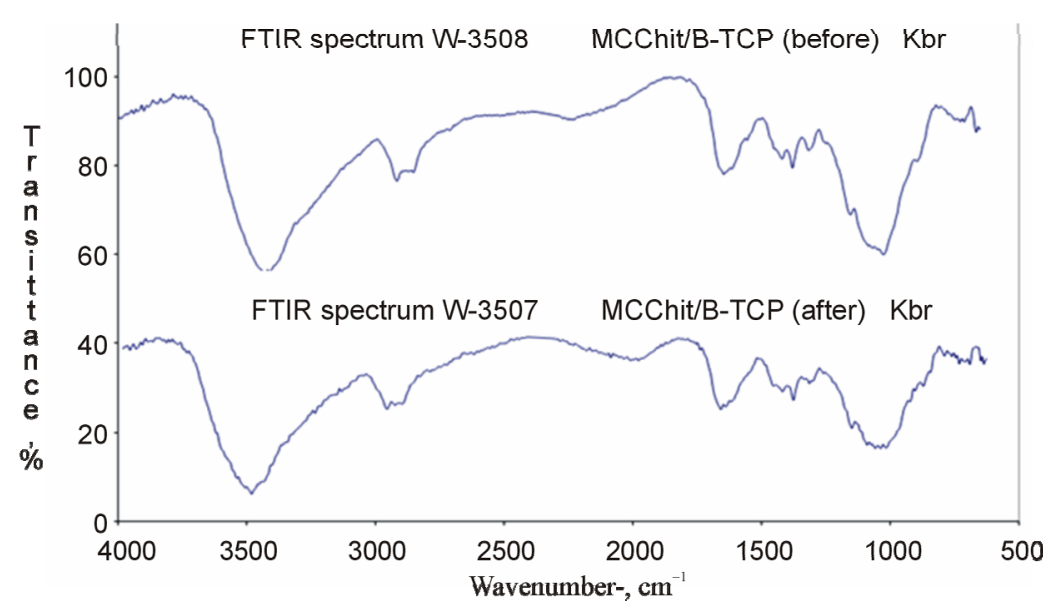

Figure 2. FTIR spectrum of the MCCh/ß-TCP before and after purification process.

In the composite, the absence of bands at 460 and 740 $\left(\mathrm{cm}^{-1}\right)$ and an isolated band, $600 \mathrm{~cm}^{-1}$; characteristic of a-TCP, indicating that the starting material is only composed of $\beta-T C P$, also shows a small amount of $\mathrm{CO}_{3}^{-2}$ in
$1428 \mathrm{~cm}^{-1}$. This calcium phosphate is easily identified by presenting a broad band in $900-1200 \mathrm{~cm}^{-1}$; observed the presence of the peak at $724 \mathrm{~cm}^{-1}$, characteristic of the symmetric mode (P-O-P) assigned to distortion of $\mathrm{P}-\mathrm{O}$. 
Since the peak at $1211 \mathrm{~cm}^{-1}$ is characteristic of a nondegenerate deformation of hydrogen groups $-\mathrm{OPO}_{3},-\mathrm{H}$, $\mathrm{O}-\mathrm{PO}_{3}$, common ions $\mathrm{HPO}_{4}^{-2}$, the presence of this group may be a consequence of the interaction of water molecules in the structure [18,20-22].

Also in the composite samples showed in $3338 \mathrm{~cm}^{-1}$ and $1650 \mathrm{~cm}^{-1}$ the $\mathrm{O}-\mathrm{H}, \mathrm{H}-\mathrm{O}-\mathrm{H}$ group peak, referring to the adsorbed water. The peak observed at $968 \mathrm{~cm}^{-1}$ of low intensity, corresponds to non-degenerate symmetric stretching of P-O bonds of phosphate groups. The bands 1041, 1081 and $1098\left(\mathrm{~cm}^{-1}\right)$ represent the asymmetric stretch modes, respectively, the P-O bonds of phosphate groups $[8,18,21]$.

In the composite is confirmed also the presence of the functional groups $\mathrm{NH}_{2}\left(1539 \mathrm{~cm}^{-1}\right)$, Amide I $\left(1648 \mathrm{~cm}^{-1}\right)$, amide II $\left(1557 \mathrm{~cm}^{-1}\right)$ from MCCh material. The main peaks of energy $\left(1026,1086 \mathrm{~cm}^{-1}\right)$ identified the C-O skeletal vibrations stretch of saccharide structure.

The peak observed at $1154 \mathrm{~cm}^{-1}$, of high intensity, corresponds to anti-symmetric stretching of C-O-C bond groups. The bands 1026 and $1086\left(\mathrm{~cm}^{-1}\right)$ represent the symmetric stretch modes, respectively, the $\mathrm{C}-\mathrm{O}$ bonds characteristics of the saccharide structure groups $[16,21$, 23]. The Figure 2 shows the FTIR spectra of complex before and after purification process. The spectrum exhibits peaks of the same characteristic such as: a strong and broad peak between $1154 \mathrm{~cm}^{-1}$ and $1026 \mathrm{~cm}^{-1}$ and $1086 \mathrm{~cm}^{-1}$ that refer to the skeletal vibrations stretch of saccharide structure and a peak at $1636 \mathrm{~cm}^{-1}$ attributed to the free primary amino group $\left(\mathrm{NH}_{2}\right)$ in $\mathrm{MCCh}[16,21,23]$. The main peaks of energy vibration identified in the $\beta$-TCP are characteristic functional groups of orthophosphate $\left(\mathrm{PO}_{4}^{-3}\right)$ at $1100 \mathrm{~cm}^{-1}$, hydroxyl $(\mathrm{OH})^{-}$at $3430 \mathrm{~cm}^{-1}$, phosphate $\left(\mathrm{HPO}_{4}^{-2}\right)$ at $1000 \mathrm{~cm}^{-1}$.

A broad peak appears from $3338 \mathrm{~cm}^{-1}$ corresponding to the $-\mathrm{OH}$ stretching absorption band in the samples. The chemical interactions between the inorganic and organic constituents in the composite, probably take place via the ionic and electrostatic bonding between $\mathrm{Ca}^{2+}$, phosphate groups and the amino group of chitosan, that confirm the positive charge of the MCCh and the negative charge of the $\beta$-TCP $[21,23]$.

The FTIR spectrum before and after purification process show very similar peaks that suggest the same product, validating the method of preparation of $\mathrm{MCCh} /$ ß-TCP.

\subsection{SEM Study of the Sponges}

The objective of the investigation was to estimate the B-TCP and HAP, suitability in the sponge preparations form and distribution in the polymer matrix, showed in the Figures 3-5 and according with Table 1.

The preparations of composites sponges formed a well-shaped 3-dimensional structure and interconnected porous. This was also supported by the high porosity which can be used in future as a base for scaffolds production. The crystals of HAp and B-TCP and clusters formation from both calcium phosphates aggregate well in the polymer matrix. Addition of MCCh in powder form in the suspension doesn't affect the uniformity and distribution of the HAp and B-TCP in the polymer matrix showed in Figure 6. The SEM analysis showed great ability of calcium phosphates to agglomerate, the small particles tend to agglomerate due to the increased intensity of the attraction forces compare to repulsive forces,

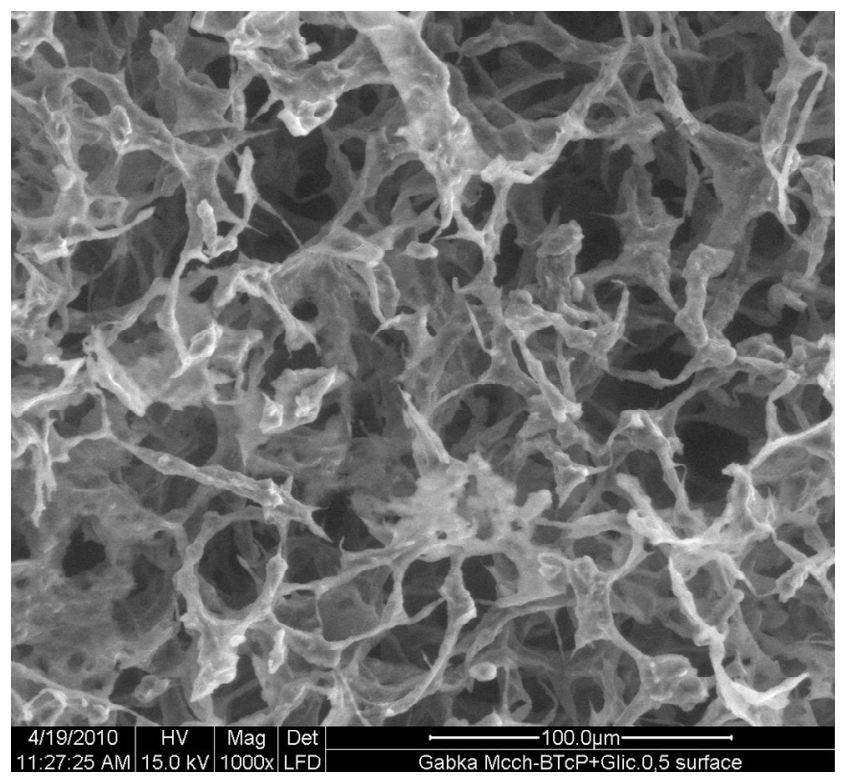

(a)

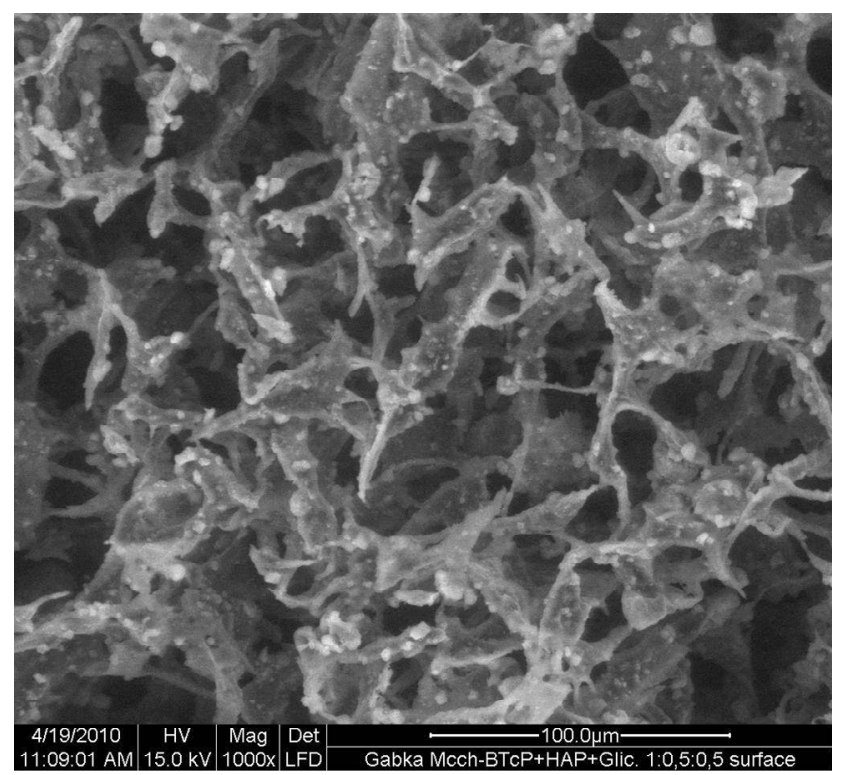

(b)

Figure 3. SEM microphotos cross-section 1000× (a), sample 1 (b) sample 2. 


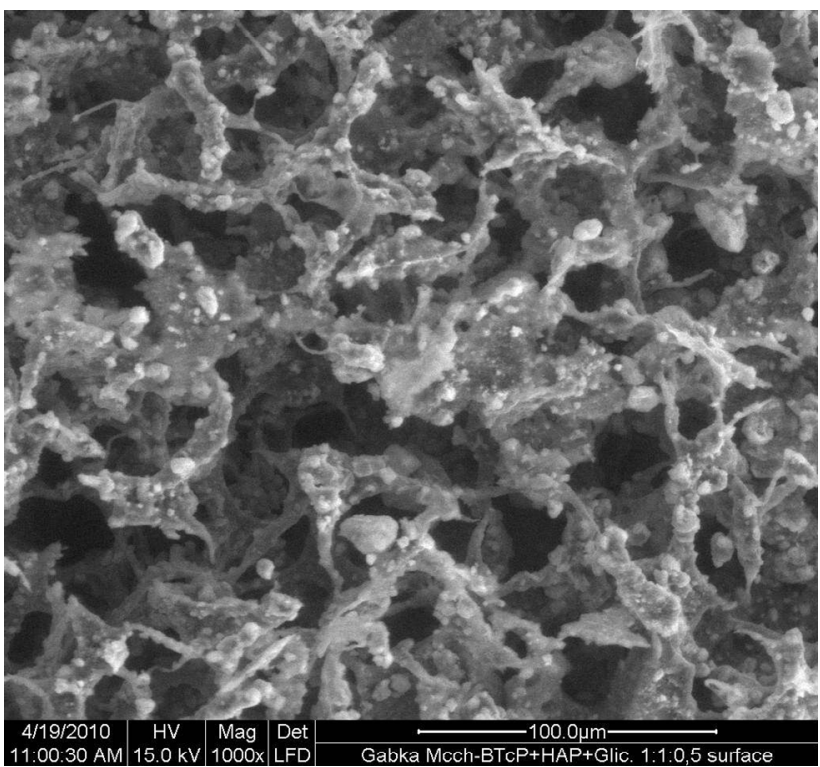

(a)

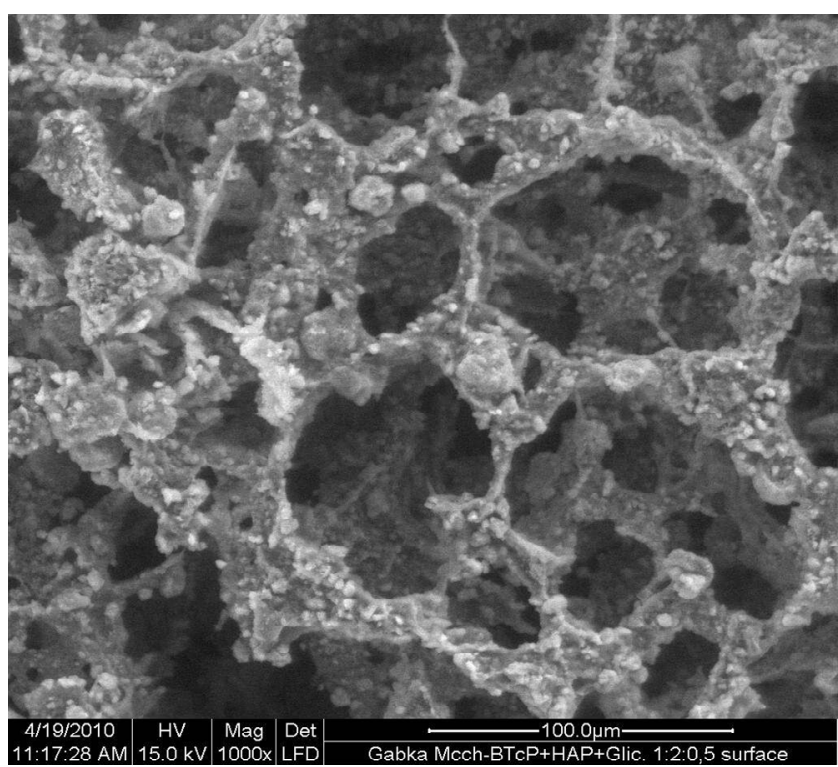

(b)

Figure 4. SEM microphotos cross-section 1000× (a), sample 3 (b) sample 4.

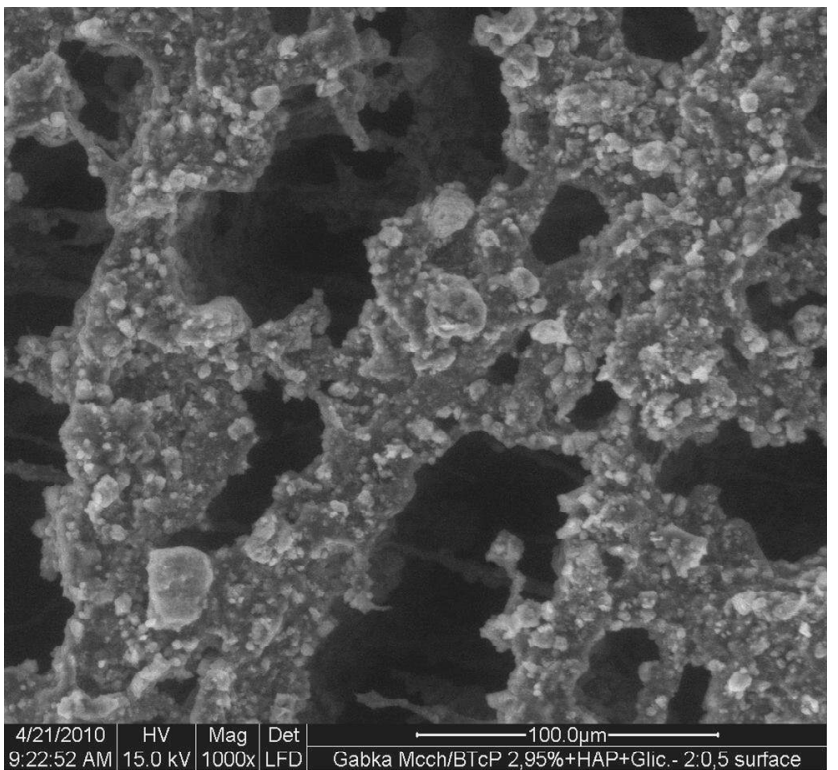

(a)

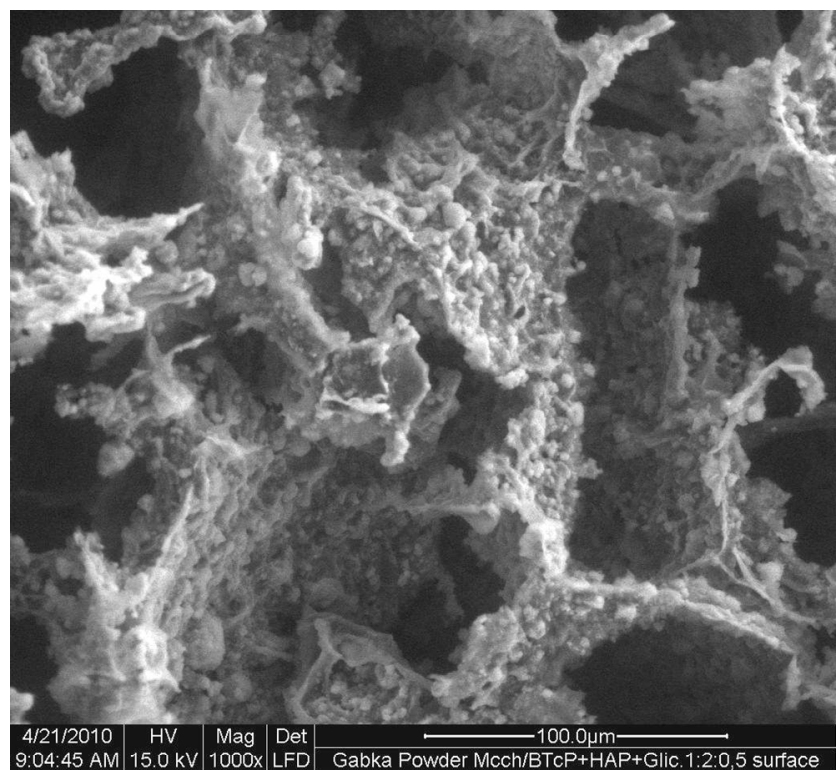

(b)

Figure 5. SEM microphotos cross-section 1000× (a), sample 5 (b) sample 6.

because the charge distribution on the surfaces and the water adsorption. The addition of hydroxyapatite gradually increased the rough surface.

\subsection{X-Ray Diffraction}

The aim of this study is to confirm the crystalline and amorphous phases of the HAp, B-TCP powders showed in Figure 6.

The crystalline phase of powders is directed related with calcium phosphate dissolution and less time for new tissue stimulation and formation [20].
However the intensity of peak at $32.5^{\circ}$ and the intensities of peaks at $26^{\circ}$ and $40^{\circ}$ is also a characteristic peaks of HAp. Regarding that the peaks values were observed, the structure showed is hydroxyapatite and no different new crystal phase was observed in the Figure 6. The increased sharpness and intensities and decreased broadness of mentioned peaks can be explained by the increase in crystal sizes according with particles size analyses showed in Section 3.4, relatively small crystals of the HAp and B-TCP which were in powders form and with particle size range less than 10 microns. 
The X-ray diffraction of the calcium phosphate powders showed a considerable amorphous halo in the HAp powder between $10^{\circ}<2 \theta<20^{\circ}$, the $\beta$-TCP was found to be completely amorphous.

In material applications for engineering tissue regeneration, the relatively high solubility of amorphous calcium phosphate in aqueous environments make suitable or a good choice as a mineralizing agent. When compounded with appropriate polymeric material, amorphous calcium phosphate bioactivity may be particularly useful in enhancing the performance of composites in physiological environmental [19].

\subsection{Determination of Particles Size in HAp and ß-TCP Powders}

The aim of this study was to determine the particle size and morphology of the commercial HAp and B-TCP in form of powder used in this research. The Figures 7(a) and (b) show the B-TCP and HAp respectively.

Notice the morphologies of the powder differ in shape, the B-TCP powder is shown in the Figure 6(a), is more spherical that HAp powder. Also the powders showed great ability to agglomeration and cluster formation, explained by a not homogenous charge distribution on the surfaces and high ability for water adsorption. Typically the very small particles tend to agglomerate due to the increased intensity of the attractive forces over the repulsive forces, due to charge distribution on the surfaces.

The analysis of particles size shown a standard deviation cannot be given so easy. The particle size depends firstly on particle shape (aspect relation). Most calculation models refer to ball-shaped bodies. The more the particles deviate from this model the more the deviation rises. Secondly, the broadness (width) of particle size

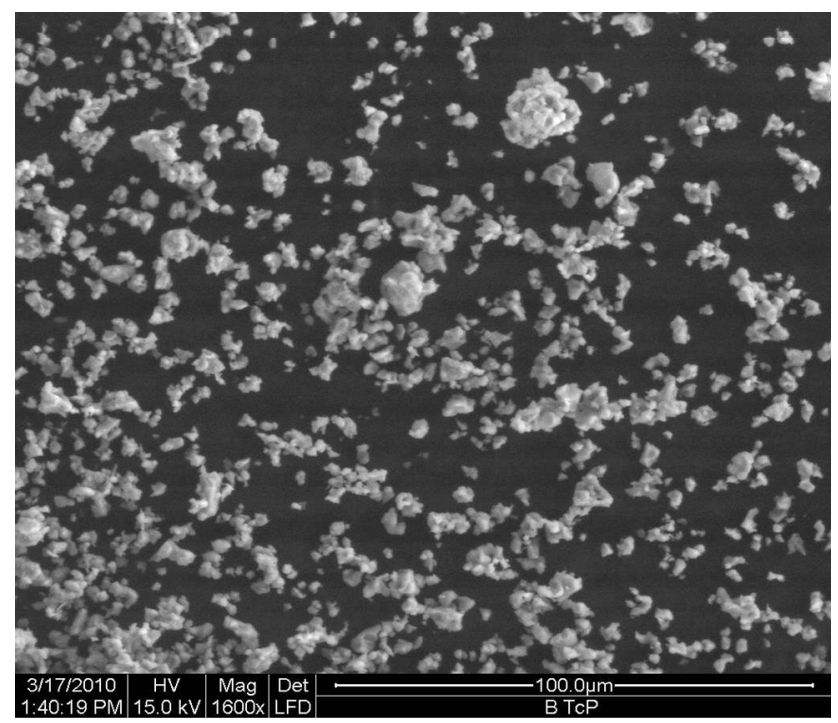

(a) distribution has an influence on the standard deviation using this method. In a case where this distribution covers only a narrow part, for instance 2 to $5 \mu \mathrm{m}$, then the deviation is lower than $10 \%$. However, the measurement itself is very precise. The measurement of the powders used in this research had procedure of three-times for each sample and receives deviations of results lower than $2 \%$, the samples of both powders had a range from 0.5 to $50 \mu \mathrm{m}$. The analysis showed a $\beta$-TCP grain size fits in the range $3.0-9.0 \mu \mathrm{m}$ and grain size of HAp fits mainly in the range $2.0-7.0 \mu \mathrm{m}$, and with fair agreement with the literature [9].

The particles size distribution graphics of the commercial calcium phosphate powders HAp and B-TCP used in this research are shown in the Figures 8 and 9 respectively.

The measurements of particles size by laser particles size gave a specified surface area covered by each powder HAp is $3.41 \mathrm{e}+04 \mathrm{~cm}^{2} / \mathrm{g}$ and B-TCP $2.53 \mathrm{e}+04$

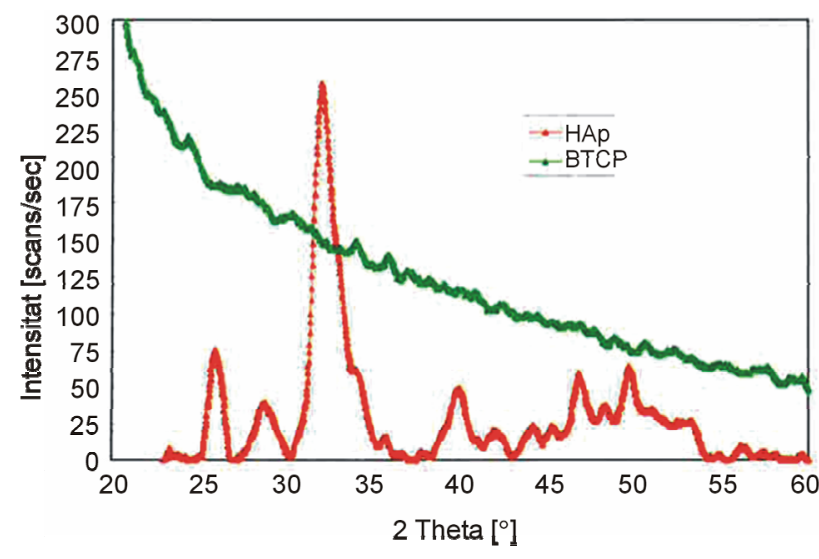

Figure 6. X-Ray spectrum of the ß-TCP and HAp powder.

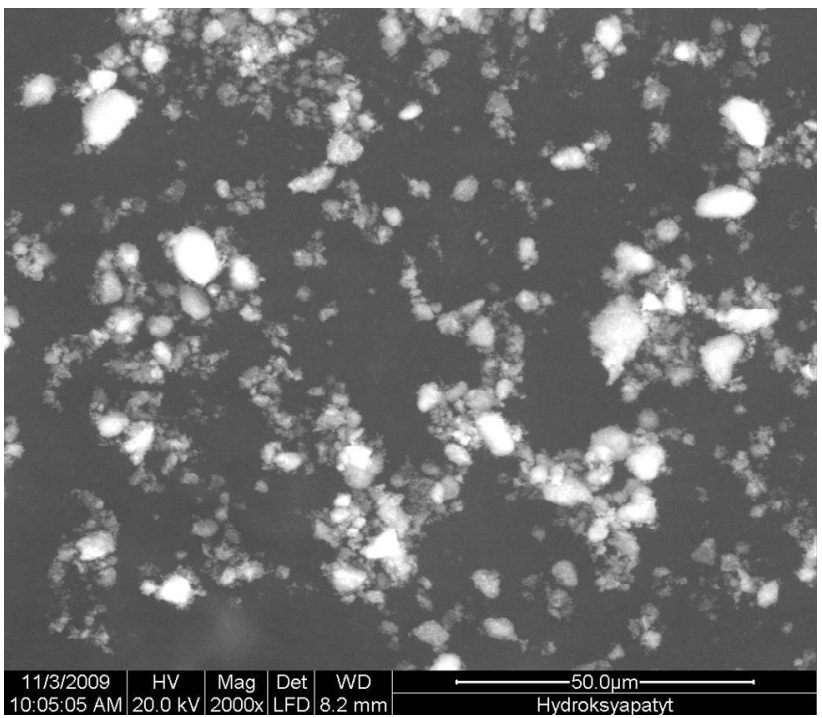

(b)

Figure 7. Morphology of particles of the commercial ß-TCP and HAp respectively, powder form. 


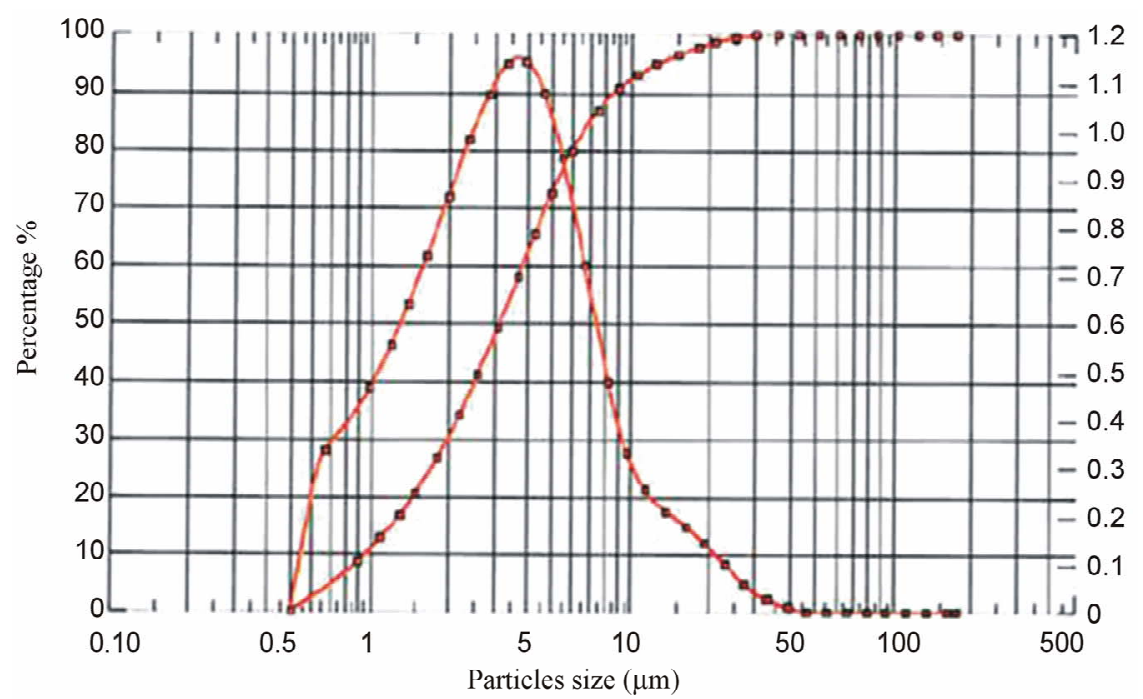

Figure 8. Grain size and distribution of synthetic HAp powder.

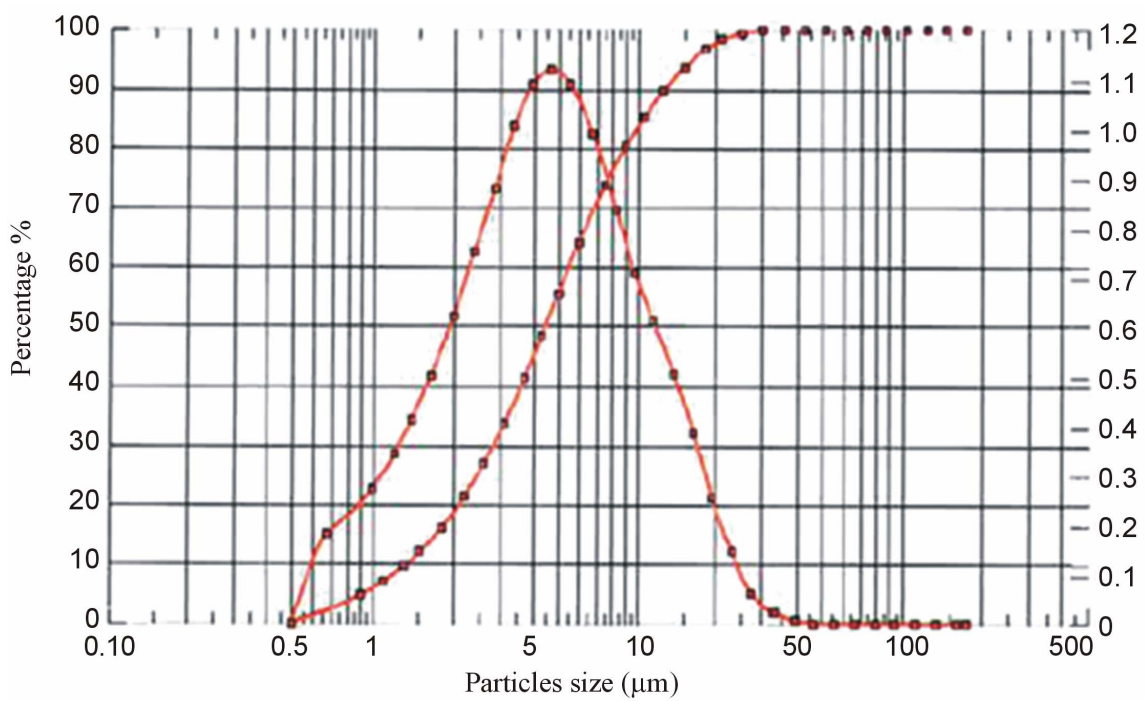

Figure 9. Grain size and distribution of synthetic ß-TCP powder.

$\mathrm{cm}^{2} / \mathrm{g}$ (Table 2). Also it was found around $10 \%$ of the calcium phosphate particles used in this research (HAp and $B$-TCP) was nano size that also indicate a faster and easier release of calcium and phosphate ions in physiological environmental following the literature $[9,19]$. There are many factors related with the performance of the biocomposite for hard tissue regeneration that reflect in the preparation of suspension, mechanical properties and calcium and phosphate ions in the physiological environmental as a particles size, shape, particles distribution and also ratio of inorganic part in the polymer matrix.

\subsection{Determination of $\mathrm{Ca}$ and $\mathrm{P}$ Content in Composites}

The aim of this analyze is to determine the content of $\mathrm{Ca}$ and $\mathrm{P}$ that remains after sponges preparation. This relation is also mentioned in the literature that minerals in study are the most important elements for hard tissue regeneration activity and are direct related with calcium phosphate dissolution and less time for new tissue stimulation $[9,19]$. Table 3 shows the proportion of the $\mathrm{Ca}$ and $\mathrm{P}$ in composites using complex as a base for preparations.

The presence of $\mathrm{Ca}$ and $\mathrm{P}$ in the samples describes a good relation between those materials involved, suggesting a good bone tissue regeneration activity. The cationic nature of the HAp and microcrystalline chitosan and anionic nature of the $\beta$-TCP also responsible for high electrostatic bounding reflect in the structure, a ceramic composite formation in all preparations that also is related with solubility and viscosity of the composite in the 
Table 2. Particles size of commercial HAp and ß-TCP.

\begin{tabular}{ccc}
\hline POWDERS & HAp & B-TCP \\
\hline Particles size $(90 \%),(\mu \mathrm{m})$ & 8.81 & 12.78 \\
Particles size $(50 \%),(\mu \mathrm{m})$ & 3.16 & 4.48 \\
Particles size $(10 \%),(\mu \mathrm{m})$ & 0.97 & 1.35 \\
Superficial area $\left(\mathrm{cm}^{2} / \mathrm{g}\right)$ & $3.41 \mathrm{e}+04$ & $2.53 \mathrm{e}+04$ \\
\hline
\end{tabular}

Table 3. Weight proportion of $\mathrm{Ca}$ and $\mathrm{P}$ composites.

\begin{tabular}{|c|c|c|c|}
\hline \multirow{2}{*}{$\begin{array}{l}\text { Symbol of sample } \\
\text { (film form) }\end{array}$} & \multicolumn{3}{|c|}{ Proportion of $\mathrm{Ca}$ and $\mathrm{P}$} \\
\hline & Composites & $\begin{array}{c}\mathrm{Ca} \\
(\mathrm{ppm})\end{array}$ & $\begin{array}{c}\mathrm{P} \\
(\mathrm{ppm})\end{array}$ \\
\hline HAp powder & Initial & 447,200 & 186,500 \\
\hline ß-TCP powder & Initial & 425,400 & 199,000 \\
\hline $\mathrm{MCCh}$ & Initial & 108 & 186 \\
\hline $\begin{array}{c}\mathrm{MCCh} / ß-\mathrm{TCP} \\
\text { complex }\end{array}$ & Initial & 53600 & 28,200 \\
\hline (Sample 1) & $\begin{array}{c}\text { MCCh/ß-TCP } \\
\text { complex/glycerol } \\
(1: 0.5 \mathrm{wt} \%)\end{array}$ & 42100 & 23,500 \\
\hline (Sample 2) & $\begin{array}{c}\text { MCCh/ß-TCP complex/ } \\
\text { HAp/glycerol (1:0.5:0.5 } \\
\text { wt } \%)\end{array}$ & 115,000 & 51,700 \\
\hline (Sample 3) & $\begin{array}{c}\mathrm{MCCh} / \mathrm{\beta}-\mathrm{TCP} \text { complex } \\
\text { /HAp/glycerol } \\
(1: 1: 0.5 \mathrm{wt} \%)\end{array}$ & 148,000 & 66,400 \\
\hline (Sample 4) & $\begin{array}{c}\text { MCCh/B-TCP complex } \\
\text { /HAp/glycerol } \\
(1: 2: 0.5 \mathrm{wt} \%)\end{array}$ & 183,000 & 80,800 \\
\hline (sample 5) & $\begin{array}{c}\text { MCCh/B-TCP complex } \\
\text { /HAp/glycerol } \\
(1: 2: 0.5 \mathrm{wt} \%)\end{array}$ & 185,000 & 82,100 \\
\hline (Sample 6) & $\begin{array}{c}\mathrm{MCCh} / \mathrm{\beta}-\mathrm{TCP} \text { complex } \\
\text { /HAp/glycerol } \\
(1: 2: 0.5 \mathrm{wt} \%)\end{array}$ & 158,000 & 70,000 \\
\hline
\end{tabular}

physiological environmental. The results showed a relation between $\mathrm{Ca}$ and $\mathrm{P}$ approximately $2 / 1$ (wt $\%$ ) respectively, that show a high ppm content of $\mathrm{Ca}$ and $\mathrm{P}$ in all samples.

\section{Conclusions}

Based on the study it should be noted:

1) The FTIR analysis of the composites showed a characteristic peak of MCCh, B-TCP and HAp in the samples, validating also the method to obtain the complex.

2) The X-ray diffraction of the calcium phosphate powders showed a considerable amorphous halo in the commercial HAp between $10^{\circ}<2 \theta<20^{\circ}$, and the B-TCP was found to be completely amorphous.

3) The SEM analysis showed a $\beta-T C P$ and HAP grain size mainly in the range of $10 \mu \mathrm{m}$, average particle size of $12.78 \mu \mathrm{m}$ and $8.81 \mu \mathrm{m}$. The composite sponges showed a homogenous distribution of the calcium phosphate blend in the polymer matrix with homogeneous and interconnected porous microstructure.

4) The high content of $\mathrm{Ca}$ and $\mathrm{P}$ in the composites showed a relation approximately $2 / 1$ (wt $\%$ ) respectively, and very high content of calcium and phosphate ions.

5) The study showed the feasibility of freeze drying method which resulted in three dimensional interconnected micro-porous network structure, which could be used in the future as a scaffold material.

\section{Acknowledgements}

The research and the work presented herewith was carried out with financial support by the European Community's Seventh Framework Program ("Marie Curie Initial Training Network), FP7/2007-2013.

Thuringian Institute of Textile and Plastics Research, Rudolstadt, Germany.

\section{REFERENCES}

[1] M. A. Barbosa, P. L. Granja, C. C. Barrias and I. F. Amaral, "Polysaccharides as Scaffolds for Bone Regeneration," ITBM-RBM, Vol. 26, No. 3, 2005, pp. 212-217. http://dx.doi.org/10.1016/j.rbmret.2005.04.006

[2] Oktay YILDIRIM, "Preparation and Characterization of Chitosan /Calcium Phosphate Based Composite Biomaterials," Master Of Science Dissertation, İzmir Institute of Technology, İzmir, 2004.

[3] R. A. A. Muzzarelli, "Chitin and the Human Body," 1st International Conference of the European Chitin Society on Advances in Chitin Science, Brest, 11-13 September 1995, pp. 448-461.

[4] J.-Y. Lee, S.-H. Nam, S.-Y. Im, Y.-J. Park, Y.-M. Lee, Y.-J. Seol, C.-P. Chung and S.-J. Lee, "Enhanced Bone Formation by Controlled Growth Factor Delivery from Chitosan-Based Biomaterials," Journal of Controlled Release, Vol. 78, No. 1-3, 2002, pp. 187-197. http://dx.doi.org/10.1016/S0168-3659(01)00498-9

[5] D. J. Misiek, J. M. Kent and R. F. Carr, "Soft Tissue Responses to Hydroxyapatite Particles of Different Shapes," Journal of Oral and Maxillofacial Surgery, Vol. 42, No. 3, 1984, pp. $150-160$.

http://dx.doi.org/10.1016/S0278-2391(84)80025-7

[6] M. Vert, M. S. Li, G. Spenlehauer and P. Guerin, "Bioresorbability and Biocompatibility of Aliphatic Polyesters," Journal of Materials Science: Materials in Medicine, Vol. 3, No. 6, 1992, pp. 432-446.

[7] D. W. Hutmacher, "Scaffolds in Tissue Engineering Bone and Cartilage," Biomaterials, Vol. 21, No. 24, 2000, pp. 2529-2543.

[8] M. H. Fathi, A. Hanifi and V. Mortazavi, "Preparation and Bioactivity Evaluation of Bone-Like Hydroxyapatite Nanopowder," Journal of Materials Processing Technology, Vol. 202, No. 1-3, 2008, pp. 536-542.

[9] S.-H. Kwon, Y.-K. Jun, S.-H. Hong and H.-E. Kim, "Syn- 
thesis and Dissolution Behavior of B-TCP and HA/BTCP Composite Powder," Journal of European Ceramic Society, Vol. 23, No. 7, 2003, pp. 1039-1045. http://dx.doi.org/10.1016/S0955-2219(02)00263-7

[10] H. Ç. Arca and S. Şenel, "Chitosan Based Systems for Tissue Engineering Part 1: Hard Tissues," Journal of Pharmaceutical Sciences, Vol. 33, 2008, pp. 35-49.

[11] R. A. A. Muzzarelli, "Chitosan Composites with Inorganics, Morphogenetic Proteins and Stem Cells, for Bone Regeneration," Carbohydrate Polymers, Vol. 83, No. 4, 2011, pp. 1433-1445. http://dx.doi.org/10.1016/j.carbpol.2010.10.044

[12] S.-J. Ding, "Preparation and Properties of Chitosan/Calcium Phosphate Composites for Bone Repair," Dental Materials Journal, Vol. 25, No. 4, 2006, pp. 706-712. http://dx.doi.org/10.4012/dmj.25.706

[13] M. Rinaudo, "Chitin and Chitosan: Properties and Applications," Progress in Polymer Science, Vol. 31, No. 7, 2006, pp. 603-632. http://dx.doi.org/10.1016/j.progpolymsci.2006.06.001

[14] M. N. V. R. Kumar, "A Review of Chitin and Chitosan Applications," Reactive \& Functional Polymers, Vol. 46, No. 1, 2000, pp. 1-27. http://dx.doi.org/10.1016/S1381-5148(00)00038-9

[15] M. Kucharska, A. Niekraszewicz, M. Wisniewska-Wrona, E. Wesolowska and H. Struszczyk, "Dressing Sponges Made of Chitosan and Chitosan-Alginate Fibrids," Progress on Chemistry and Application of Chitin and Its Derivatives, Vol. IX, PTChit, 2003, pp. 69-72.

[16] K. H. Bodek, "Evaluation of Properties Microcrystalline Chitosan as a Drug Carrier," Acta Poloniac Pharmaceutica, Vol. 57, No. 6, 2000, pp. 431-441.

[17] M. Sakkinen, J. Marvola, H. Kanerva, K. Lindevall, M. Lipponen, T. Kekki, A. Ahonen and M. Marvola, "Gamma Scintigraphic Evaluation of the Fate of Microcrystalline Chitosan Granules in Human Stomach," European Jour- nal of Pharmaceutics and Biopharmaceutics, Vol. 57, No. 1, 2004, pp. 133-143.

http://dx.doi.org/10.1016/S0939-6411(03)00097-3

[18] R. Fujita, A. Yokoyama, Y. Nodasaka, T. Kohgo and T. Kawasaki, "Ultrastructure of Ceramic-Bone Interface Using Hydroxyapatite and B-Tricalcium Phosphate Ceramics and Replacement Mechanism of B-Tricalcium Phosphate in Bone," Tissue \& Cell, Vol. 35, No. 6, 2003, pp. 427-440.

http://dx.doi.org/10.1016/S0040-8166(03)00067-3

[19] D. Skrtic, J. M. Antonucci and E. D. Eanes, “Amorphous Calcium Phosphate-Based Bioactive Polymeric Composites for Mineralized Tissue Regeneration," Journal of Research of the National Institute of Standards and Technology, Vol. 108, No. 3, 2003, pp. 167-182. http://dx.doi.org/10.6028/jres.108.017

[20] S.-C. Liou and S.-Y. Chen, "Transformation Mechanism of Different Chemically Precipitated Apatitic Precursor into B-Tricalcium Phosphate upon Calcinations," Biomaterials, Vol. 23, No. 23, 2002, pp. 4541-4547. http://dx.doi.org/10.1016/S0142-9612(02)00198-9

[21] D. A. Skoog, F. J. Holler and T. A. Nieman, "Principios de analise Instrumental," 5th Edition, Bookman, Brazil, 2006, pp. 342-384.

[22] J. Pena and M. Vallet-Regi, "Hydroxyapatite, Tricalcium Phosphate and Biphasic Materials Prepared by a Liquid Mix Technique," Journal of European Ceramic Society, Vol. 23, No. 10, 2003, pp. 1687-1696. http://dx.doi.org/10.1016/S0955-2219(02)00369-2

[23] J. Brugnerotto, J. Lizardi, F. M. Goycoolea, W. ArgüellesMonal, J. Desbrières and M. Rinaudo, "An Infrared Investigation in Relation with Chitin and Chitosan Characterization," Polymer, Vol. 42, No. 8, 2001, pp. 3569-3580. http://dx.doi.org/10.1016/S0032-3861(00)00713-8 